\title{
Innovation of Watermelon Skin to Watermelon Skin Slice Jam
}

\author{
Slamet Widodo, Gawarti \\ Family Welfare Education, Faculty of Engineering, Universitas Negeri Makassar \\ Makassar, Indonesia \\ slamet.widodo@unm.ac.id
}

\begin{abstract}
The study was focused: watermelon skin slice jam wasaccepted by the community. Objective: produce well-liked slice jam from watermelon skin. Ingredients: watermelon (skin part), granulated sugar, jelly, and bread (as ingredients in jam favorite test). Experiment research,data collection: hedonic quality organoleptic test: 7 scales of color (light-dark), aroma: (not fragrant-fragrant), texture (soft-hard), taste (bland-tasty), overall (bad-good), 11 scales of likes/hedonic (dislike-like). This study was involved 43 panelists. Analysis: mean, ANOVA test, Duncan test. The result:The more jellies that was added produce the lighter of color, more fragrant, harder, better, better but acceptance was not accepted.The best quality for watermelon skin slice jam was add $5 \%$ jely of total ingredients $/ 100 \mathrm{~g}$, with color/light brown, aroma/quite fragrant, taste/good, overall/good, hedonic/like.
\end{abstract}

Keywords—organoleptic test; slice jam; watermelon skin

\section{INTRODUCTION}

Watermelon is one of the well-liked fruits by the community, and it contains $93.4 \mathrm{~g}$ water, $0.5 \mathrm{~g}$ protein, $5.3 \mathrm{~g}$ carbohydrate, $0.1 \mathrm{~g}$ fat, $0.2 \mathrm{~g}$ fiber, $0.7 \mathrm{~g}$ ash, and vitamins $(\mathrm{A}, \mathrm{B}$, and $\mathrm{C}$ ), with $6 \mathrm{mg}$ vitamin $\mathrm{C}$ per $100 \mathrm{~g}$ ingredients. Watermelon is often found during the dry season. Currently, watermelon juicy flesh is often consumed, yet the skin is disposed [1,2].

The watermelon skin excess during harvest season that is disposed has many benefits that aren't well-known by the society. The benefit are high nutrient content of water, and high potassium to neutralize blood pressure, antioxidant including beta-carotene, vitamin $\mathrm{C}$, and phenolic to help the cells stay healthy, and food and nutraceutical functions for food industry $[3,4]$. Consumption of watermelon juice can modulate oxidative damage caused by low-dose X-ray exposure [5-7].

The potential for watermelon skin includes dysentery, tumors, heart complaints, stomach acidity, and liver disorder treatment [8]. In addition, the excess of watermelon skin can be processed into food ingredient to improve the economy of community. Therefore, the watermelon skin potential can be utilized to be processed into several food products with high economic value. Those products include watermelon skin jam, sweetmeat, or watermelon skin juice [9].

Jam is a thick, semi-solid food, made from a mixture and part of fruits and high sugar as a composition for ripe fruits. In producing jam, fiber that is not soluble in water is needed to maintain a semi-solid structure of jam. The jam can be utilized as a source of fiber in jam making. The commercial jam in the market is usually in the form of paste or spread for bread[10].

Related to that, the innovation of watermelon skin slice jam processing and formulation is needed. The hope is these ingredients and formulation is need. The hope is these ingredients that haven't been consumed and disposed of directly will disrupt the public's health because of the odor generated. Thus, the study is conducted in order to produce watermelon skin slice jam that is well-liked by the community.

\section{METHODS}

\section{A. Place and Time Of Study}

The study is conducted from March to June 2017. The place to formulate slice jam and testing (hedonic quality and hedonic) is at PKK Laboratory Universitas Negeri Makassar

\section{B. Ingredients and Equipment}

Ingredients and equipment used in the implementation include: watermelon (skin part), granulated sugar, jelly, and bread (as ingredients in jam favorite test); equipment used, among others, are stove, frying pan, spatula, pan, coconut grater, measuring glass filter, scales, knife

\section{Data Collection Method}

The data collected in the form of the process of making watermelon skin slice jam, descriptive to obtain the data of the process of making watermelon skin slice jam. The data for watermelon skin slice jam is received through score sheet related to the quality of slice jam (color, scent, texture, taste, and overall), and level of preferences of watermelon skin slice jam (dislike-like). The color data includes 7 scales, starting from very dark brown - very light brown, 7 scales of aroma are very not fragrant - very fragrant, 7 scales of texture are very soft (mushy) - very hard, 7 scales of taste are very bland - very tasty, the overall data with 7 scales starts from very bad-very good, and the likes/hedonic consists of 11 scales, starting from extreme dislike to extreme like. This study was involved 43 panelists [11]

\section{Data Analysis}

In this study, data of watermelon skin slice jam is processed by using qualitative descriptive method. The best data reception and liked by the panelist (hedonic quality and hedonic) uses mean, ANOVA test, and Duncan test. 


\section{RESULT AND DISCUSSION}

\section{A. Manufacture of Watermelon Skin Slice Jam}

The process of making watermelon skin slice jams begins with the process to prepare the ingredients and equipment, the ingredients is cleaned (watermelon) by washing with clean water to obtain a clean watermelon free from dust and dirt on the watermelon. the next process is to skin the watermelon skin to reveal the inside skin that is more white, and afterward, to separate the colored part of the watermelon (the part that tastes sweet on the watermelon and the most frequently consumed). afterward, the white watermelon skin is grated by using the coconut grater. the grated method aims to obtain the soft watermelon skin and still has the coarse/fibrous texture of the watermelon skin, as well as to improve/maintain the characteristic of watermelon. the next process is to squeeze the watermelon skin. this process aims to reduce the water content in the watermelon skin to accelerate the jam making process. afterward, the process to weigh each ingredient based on the determined formula.the process of making watermelon skin slice jams as figure 1 .


Fig 1. The slice jam process

The slice jam process begins with the process of making caramel with sugar, and it uses the grated watermelon skin as the liquid ingredients. The next process is to cook the watermelon for 30 minutes, and to add caramel, the water from grated watermelon skin, gel flour, according to the formula, for 30 minutes. Afterward, the cooling process is to flatten the jam on baking pan with $2-3 \mathrm{~mm}$ thickness. After it cools down, the watermelon skin slice jam is cut with length and width of $10 \mathrm{~cm}$, to obtain uniform size of slice jam.

\section{B. Characteristic of Watermelon Skin Slice Jam}

The jam characteristics are the results obtained from the watermelon skin processing, which starts from the preparation process to the presentation to the panelist related to the quality in the form of color, scent, texture, taste, and overall quality. Generally, the watermelon skin slice jam produced by the process has the characteristics of brown colored, caramel watermelon scent, chewy texture, sweet taste, and overall quality of good jam and consumable.

\section{Formulation of Watermelon Skin Slice Jam}

To obtain the watermelon skin slice jam that is accepted, both in quality and liking by the community/panelists, formulation is conducted on the amount of material used for the manufacture of such jam.

\section{1) StandardizationRecipe}

Standardization recipe is conducted in order to obtain standard recipe to be used in the watermelon skin slice jam processing. At the time of research, jam recipe that uses watermelon skin is not available/found. Thus, we duplicated a pineapple jam recipe and made adjustment on the sugar usage. This is due to the acidic nature of pineapple that requires more sugar than watermelon skin that does not taste sour. Recipe for $1 \mathrm{~kg}(1000 \mathrm{~g})$ pineapple jam, 800 granulated sugar (ST8). For more details, see the following Table 1 .

TABLE I. RECIPE STANDARIZATION FOR WATERMELON SKIN JAM PER $1000 \mathrm{~g}$

\begin{tabular}{|c|c|c|c|c|}
\hline Formula & $\begin{array}{c}\text { Watermelon } \\
\text { skin }\end{array}$ & Sugar & $\begin{array}{c}\text { Water of } \\
\text { water } \\
\text { melon } \\
\text { skin }\end{array}$ & Salt \\
\hline St 1 & 1000 & 500 & 750 & 2 \\
\hline St 2 & 1000 & 550 & 750 & 2.5 \\
\hline St 3 & 1000 & 600 & 750 & 3 \\
\hline St 4 & 1000 & 650 & 750 & 3.5 \\
\hline St 5 & 1000 & 675 & 750 & 4 \\
\hline St 6 & 1000 & 700 & 750 & 4.5 \\
\hline St 7 & 1000 & 750 & 750 & 5 \\
\hline St 8 & 1000 & 800 & 750 & 5.5 \\
\hline
\end{tabular}

Based on Table 1, reception tests, both hedonic quality (color, aroma, texture, taste, and overall), and hedonic (likeness) are conducted. The data of acceptance is presented in the following Table 2.

TABLE II. THE ORGANOLEPTIC TEST RESULT OF WATERMELON SKIN JAM RECIPE STANDARIZATION

\begin{tabular}{|c|c|c|c|c|c|c|}
\hline Formulas & Color & Aroma & Texture & Taste & over all & Acceptance \\
\hline ST1 & $(3,56 \pm 0,5)^{\mathrm{a}}$ & $(2,44 \pm 0,5)^{\mathrm{a}}$ & $(2,44 \pm 0,5)^{\mathrm{a}}$ & $(4,75 \pm 0,9)^{\mathrm{a}}$ & $(5,00 \pm 1)^{\mathrm{a}}$ & $(7,31 \pm 1)^{\mathrm{a}}$ \\
\hline ST2 & $(3,63 \pm 0,5)^{\mathrm{a}}$ & $(2,38 \pm 0,5)^{\mathrm{a}}$ & $(2,31 \pm 0,5)^{\mathrm{a}}$ & $(4,88 \pm 0,6)^{\mathrm{a}}$ & $(5,44 \pm 0,6)^{\mathrm{ab}}$ & $(7,81 \pm 0,9)^{\mathrm{ab}}$ \\
\hline ST3 & $(3,63 \pm 0,6)^{\mathrm{a}}$ & $(2,44 \pm 0,5)^{\mathrm{a}}$ & $(2,31 \pm 0,5)^{\mathrm{a}}$ & $(4,88 \pm 1)^{\mathrm{a}}$ & $(5,56 \pm 0,6)^{\mathrm{bcc}}$ & $(8,31 \pm 0,7)^{\mathrm{bcd}}$ \\
\hline ST4 & $(3,69 \pm 0,6)^{\mathrm{a}}$ & $(2,38 \pm 0,5)^{\mathrm{a}}$ & $(2,31 \pm 0,5)^{\mathrm{a}}$ & $(5,00 \pm 1)^{\mathrm{a}}$ & $(5,69 \pm 0,5)^{\mathrm{bc}}$ & $(8,69 \pm 0,5)^{\mathrm{de}}$ \\
\hline ST5 & $(3,81 \pm 0,7)^{\mathrm{a}}$ & $(2,31 \pm 0,5)^{\mathrm{a}}$ & $(2,31 \pm 0,5)^{\mathrm{a}}$ & $(5,25 \pm 0,8)^{\mathrm{a}}$ & $(6,06 \pm 1)^{\mathrm{c}}$ & $(9,00 \pm 0,6)^{\mathrm{a}}$ \\
\hline ST6 & $(3,75 \pm 0,5)^{\mathrm{a}}$ & $(2,25 \pm 0,5)^{\mathrm{a}}$ & $(2,25 \pm 0,5)^{\mathrm{a}}$ & $(5,13 \pm 0,8)^{\mathrm{a}}$ & $(5,81 \pm 0,5)^{\mathrm{bc}}$ & $(8,56 \pm 0,7)^{\mathrm{cde}}$ \\
\hline ST7 & $(3,69 \pm 0,6)^{\mathrm{a}}$ & $(2,38 \pm 0,5)^{\mathrm{a}}$ & $(2,31 \pm 0,5)^{\mathrm{a}}$ & $(5 \pm 0,8)^{\mathrm{a}}$ & $(5,56 \pm 0,6)^{\mathrm{abc}}$ & $(8,25 \pm 0,9)^{\mathrm{bcd}}$ \\
\hline ST8 & $(3,69 \pm 0,5)^{\mathrm{a}}$ & $(2,31 \pm 0,5)^{\mathrm{a}}$ & $(2,25 \pm 0,5)^{\mathrm{a}}$ & $(4,94 \pm 0,9)^{\mathrm{a}}$ & $(5,44 \pm 0,7)^{\mathrm{ab}}$ & $(8,00 \pm 0,8)^{\mathrm{bc}}$ \\
\hline
\end{tabular}

Based on the organoleptic test results of watermelon skin jam recipe standardization, Standard Recipe 5 (ST5) is chosen to show the best quality acceptance and likeness level. But, all 
the product generated have shown less attractive color. Based on those results and feedback from panelists, the jam processing process is amended by changing the granulated sugar into caramel, in hope that it improves color, aroma, and taste of the jam. The picture of organoleptic test score of standardization as Figure 2 and Figure 3.



Fig 2. Organoleptic test scors from standardization

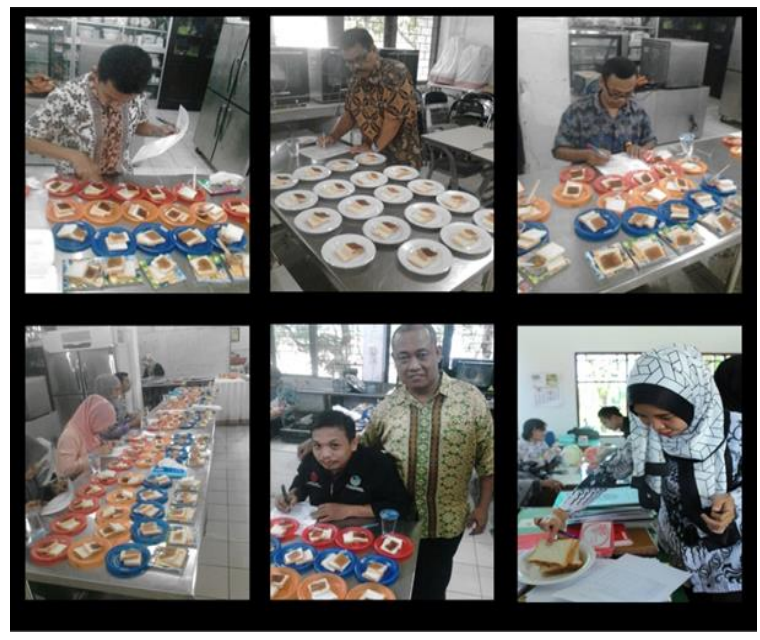

Fig 3. The picture was procces organoleptic test.

2) Slice jam formula tion.

The slice jam formulation is presented as Table 3

TABLE III. WATERMELON SKIN SLICE JAM FORMULATION PER 100g INGREDIENTS

\begin{tabular}{|c|c|c|c|c|c|c|c|}
\hline Formulas & Jely & $\begin{array}{c}\text { Watermelon } \\
\text { Skin }\end{array}$ & Caramel & $\begin{array}{c}\text { Water of } \\
\text { watermelon } \\
\text { skin }\end{array}$ & Salt & Citrum & $\begin{array}{c}\text { Total } \\
\text { Ingredients }\end{array}$ \\
\hline F0 & 0 & 42 & 26,8 & 31 & 0,1 & 0,1 & 100 \\
\hline F1 & 2,5 & 42 & 26,8 & 28,5 & 0,1 & 0,1 & 100 \\
\hline F2 & 5 & 42 & 26,8 & 26 & 0,1 & 0,1 & 100 \\
\hline F3 & 7,5 & 42 & 26,8 & 23,5 & 0,1 & 0,1 & 100 \\
\hline F4 & 10 & 42 & 26,8 & 21 & 0,1 & 0,1 & 100 \\
\hline
\end{tabular}

\section{Acceptable of Watermelon Skin Slice Jam}

The acceptance of watermelon skin slice jam in this study uses human sensory assessment or organoleptic test, with emphasis on product quality which includes color, aroma, texture, taste, and overall as well as the level of favorite on 43 panelists. The result of organoleptic taste is presented on the following Table 4 and procces of organoleptic Test of watermelon skin slice jam as Figure 3

\section{TABLE IV. THE ORGANOLEPTIC TEST RESULT OF WATERMELON SKIN SLICE JAM}

\begin{tabular}{|c|c|c|c|c|c|c|}
\hline Formulas & Color & Aroma & Texture & Taste & Overall & Acceptance \\
\hline F0 & $(3,19 \pm 0,9)^{2}$ & $(5,42 \pm 0,8)^{2}$ & $(2,58 \pm 0,6)^{2}$ & $(6,00)^{2}$ & $(6,09 \pm 0,3)^{2}$ & $(7,84 \pm 0,6)^{\mathrm{a}}$ \\
\hline F1 & $(3,33 \pm 0,9)^{2}$ & $(5,35 \pm 0,8)^{2}$ & $(4,16 \pm 0,6)^{\mathrm{b}}$ & $(6,28 \pm 0,5)^{\mathrm{bc}}$ & $(6,16 \pm 0,6)^{\mathrm{ab}}$ & $(7,93 \pm 1,2)^{\mathrm{a}}$ \\
\hline F2 & $(3,23 \pm 0,7)^{2}$ & $(5,70 \pm 0,6)^{\mathrm{a}}$ & $(4,21 \pm 0,5)^{\mathrm{b}}$ & $(6,47 \pm 0,5)^{\mathrm{c}}$ & $(6,40 \pm 0,6)^{\mathrm{b}}$ & $(8,26 \pm 1)^{\mathrm{a}}$ \\
\hline F3 & $(3,21 \pm 0,9)^{\mathrm{a}}$ & $(5,40 \pm 0,8)^{\mathrm{a}}$ & $(4,42 \pm 0,7)^{\mathrm{bc}}$ & $(6,35 \pm 0,5)^{\mathrm{bc}}$ & $(6,19 \pm 0,7)^{\mathrm{ab}}$ & $(7,91 \pm 1,3)^{\mathrm{a}}$ \\
\hline F4 & $(3,16 \pm 1)^{\mathrm{a}}$ & $(5,42 \pm 0,9)^{\mathrm{a}}$ & $(4,60 \pm 0,9)^{\mathrm{c}}$ & $(6,23 \pm 0,4)^{\mathrm{b}}$ & $(6,09 \pm 0,7)^{\mathrm{a}}$ & $(7,77 \pm 1,3)^{\mathrm{a}}$ \\
\hline Linearitas & $-0,0163$ & 0,0047 & 0,4302 & 0,0535 & 0,0023 & $-0,0163$ \\
\hline p.Value & 0,923 & 0,246 & $0,000^{* *}$ & $0,000^{* *}$ & 0,106 & 0,289 \\
\hline
\end{tabular}

Table 4 illustrates that color, aroma, overall, and hedonic shows no difference on the formula of watermelon skin slice jam. However, the texture and taste show difference in the results. Based on the average linearity of organoleptic test with additional gel shows darker color $(-0.0163)$, more fragrant aroma (0.0047), harder texture (0.4302), more tasty taste $(0.0535)$, and better overall (0.0023), and less likeness ($0.0163)$.

\section{1) Color}

ANOVA test results on the color of jam on the four formulas showed no significant difference, which means that the panelists assessed that the addition of jelly did not give any difference in the color result from the watermelon skin slice jam produced, caused by the sugar caramelization as the material in the manufacture of the slice jam. Duncan test also shows no discrepancies amongst in five formulas. The five colors of the resulting slice jam are darkish brown.Sometimes, the product color is one of the determinants of the jam quality before other factors. This is because color relates directly to a product to be favored or not favored by the consumers. The product quality is generally influenced by its forming materials, the way of processing, and the presentation of the results. When there's no caramel involved, the produced jam was slightly greenish white color and looked unappetizing. This is in line with the results of Anova and Kamsina [12,13], in which the avocado jam with palm sugar has more attractive color than the one using regular sugar. But it is different with Sundari and Koman that argued to reduce browning, citric acid or pectin can help shortening the cooking process as well as reducing browning reaction during concoction process $[11,14]$.

\section{2) Aroma.}

In general, four aromas influence the sensation received by the nose, they are fragrant, sour, rancid, and scorched. The smell of food determines the delicacy and judgment [11]. The results of average organoleptic test for hedonic quality on watermelon skin slice jam showed that all formulas showed no different aroma, which is rather fragrant. This indicates that the use of caramelized sugar gives little effect on the aroma of the jam produced. In the preliminary experiment, the jam was produced using regular sugar emitted bland aroma or even no aroma whatsoever [15]. ANOVA test showed no different 
which means panelists assess that the addition of jelly does not affect the aroma of watermelon skin slice jam produced. This is in line with opinion of Sundari and Koman[16][17], that the use of citric acid or pectin has no influence on the aroma of the jam produced.However, it differs from the opinion of Anova and Kasmina [12] that stated the use of palm sugar is very influential on the aroma of avocado jam produced. This is because palm sugar produced compound that subsequently activates ink stronger than regular sugar [18].

\section{3) Texture.}

Texture is one of the ingredients that can be perceived by thesense of touch. Texture plays an important role in the acceptance of a food product [11][19]. The hedonic quality average organoleptic test for watermelon skin slice jam on the texture of sheet produced shows a difference in the formula with the addition of gel and becomes harder. ANOVA test results showed that the addition of jelly to the watermelon skin slice jam formula makes the difference. That means the panelists assessed the increase in the amount of jelly to the formula will affect the texture of watermelon skin slice jam to be harder. Duncan advanced test showed that the standard formula (F0) differs from (F1, F2, F3, and F4), yet there's no discrepancy amongst F1, F2, F3, and F4. This is due to the added jelly that gives the effect of increasing the texture of the slice jam to be harder. The more addition of the jelly, the harder the slice jam becomes. This is in line with the opinion of Sundari and Koman (2010) that stated the addition of balanced sugars and pectin will obtain good texture, appearance, and flavor. But using too much pectin would result in hard textured jam, while using too much sugar would result in syrup-like texture [18].

\section{4) Taste.}

Taste is an important parameter and determines the consumer acceptance offood product [11]. ANOVA test results show there is a very real difference from the fifth formula of watermelon skin slice jam produced. The Duncan advanced test for thefirst formula is really different than the other three formulas. Good taste supports the acceptance of the product by consumers. Flavor compounds can provide stimulation at the time of tasting. The results of the organoleptic test on the taste quality showed all the formula resulted in good taste. The cause of good taste is the water content of the watermelon skin slice jam due to the use of caramel, the right amount of salt so as to enhance the taste of a product. This is in line with opinion of Widodo that the combination of sugar and salt will improve the taste of food $[2,11,14,15,20]$

\section{5) Overall Quality.}

The overall assessment on watermelon skin slice jam is an overall assessment on all senses, such as color, aroma, texture, and taste. ANOVA test results showed no difference from five formulas produced. It showed that the jam produced is of good qualityin average. The Duncan advanced test shows that standard formula (F0) and F4 has no difference. F1, F2, and F3 have no difference. But there isdifference in F0 and F1. This suggests that the slice jam with additional jelly influence the overall acceptance, especially on the change of jam texture $[11,14]$.

\section{6) The Acceptance of Watermelon Skin Slice Jam}

The Acceptance of watermelon skin slice jam produced through the acceptance test uses organoleptic test with 11 intervals of likeness level, from extreme dislike to extreme like. Based on Table 2, it shows that watermelon skin slice jam by all formulasare accepted by the panelists, with evidence of average result at more than 6 (hedonic middle scale), and shows 'a little bit like' except for F2 that shows the best likeness in the likeness category. This indicates that the watermelon skin slice jam is accepted, even though it becomes disliked by the panelists, as evidenced by the linearity of the reception data $(-0.0163)[6]$.

This decrease in acceptance proves that watermelon skin slice jam with added jelly is getting better and better. But, if more and more jelly is added then the acceptance decreases or in other words, to get acceptance of watermelon skin slice jam, the maximal addition is $5 \%$ of total material $100 \mathrm{~g}$ ingredients. If it exceeds then the likeness level decreases [17] [18]

\section{CONCLUSION}

The process begins with preparing the ingredients and equipment, cleaning the watermelon, separating the outside skin and inside juicy flesh, grating the watermelon skin, weighing the ingredients, cooking the ingredients, and printing, as well as cooling. The more jellies that was added produce the lighter of color, more fragrant, harder, better, better but acceptance was not accepted.The best quality for watermelon skin slice jam is to add $5 \%$ gel of total ingredients.

\section{ACKNOWLEDGMENTS}

We give our highest gratitude to the parties who have helped the study and writing process. The heads of Universitas Negeri Makassar who facilitates the study, especially Normawati, S.Pd., Kasdi Kadir and Muhammad Irwan Salam, who have been helping the formulation process of slice jam and preparing the study materials.

\section{REFERENCES}

[1] I. Gunawan, “Analisis Pendapatan Usahatani Semangka (Citrullus Vulgaris) di Desa Rambah Muda Kecamatan Rambah Hilir Kabupaten Rokan Hulu,” J. Sungkai, vol. 2, pp. 52-63, 2014.

[2] A. M. Rimando and P. M. Perkins-veazie, "Determination of citrulline in watermelon rind," J. Chromatography., vol. 1078, pp. 196-200, 2005.

[3] A. Sugeha, W. Pembengo, and F. Zakaria, "Pertumbuhan dan Hasil Tanaman Semangka (Citrullus lanatus) Pada Berbagai Macam Mulsa Organik dengan Dua Varietas yang Berbeda," J. karya Ilm. Mahasiswa.ung.ac.id, no. 1, 2015.

[4] M. A. Mushtaq Muhammad, Sultana Bushra, Bhatti Haq Nawaz, "RSM based optimized enzyme-assisted extraction of antioxidant phenolics from underutilized watermelon (Citrullus lanatus Thunb.) rind," J. Food Sci. Technol., vol. 14, pp. 1011-1019, 2014.

[5] S. Davim, S. Andrade, S. Oliveira, A. Pina, and M. J. Barroca, "Development of Fruit Jams and Juices Enriched with Fructooligosaccharides," Int. J. Fruit Sci., vol. 15, pp. 100-116, 2015.

[6] M. Khairul et al., "Juice Modulates Oxidative Damage Induced by Low Dose X-Ray in Mice,” Biomed Res. Int., vol. 2014, pp. 1-6, 2014.

[7] R. Lakshmipathy and N. C. Sarada, "Application of watermelon rind as sorbent for removal of nickel and cobalt from aqueous solution," Int. J. Miner. Process., vol. 122, pp. 63-65, 2013.

[8] A. N. Bellary, A. R. Indiramma, M. Prakash, R. 'Baskaran, and N. K. Rastogi, "Anthocyanin Infused Watermelon Rind and Its Stability 
During Storage,” Innov. Food Sci. Emerg. Technol., 2015.

[9] C. Liu, H. Hao, W. Guo, and K. Tung, "Optimal conditions for preparation of banana peels, sugarcane bagasse and watermelon rind in removing copper from water," Bioresour. Technol., vol. 119, pp. 349354, 2012.

[10] H. M. A. Al-sayed and A. R. Ahmed, "Utilization of watermelon rinds and sharlyn melon peels as a natural source of dietary fiber and antioxidants in cake," Ann. Agric. Sci., vol. 58, no. 1, pp. 83-95, 2013.

[11] S. Widodo, Yusni, and K. Kadir, "Inovasi Selai Kulit Semangka di Daerah Kabupaten Barru Provinsi Sulawesi Selatan," in Prosiding Semiloka Grassroots Innovation: Peran Inovasi Akar Rumput dalam Meningkatkan Kapasitas dan Daya Saing UKM, 2016, pp. 142-155.

[12] I. T. Anova and Kamsina, "Efek perbedaan jenis alpukat dan gula terhadap mutu selai buah,” J. Litbang Ind., vol. 3 No. 2, no. 2, pp. $91-$ 99, 2013.

[13] K. A. Athmaselvi, K. Alagusundaram, C. V Kavitha, and T. Arumuganathan, "Impact of pretreatment on colour and texture of watermelon rind," Int. Agrophys, vol. 26, pp. 235-242, 2012.

[14] S. Sirajudin, S. Widodo, Riskawati, and Ratnawati, "Acceptance Biscuits Nourishing Product With Sardines Fish And Rice Brown Flour," in Simposium Gizi Nasional: Inovasi Pangan dan Gizi Solusi Cerdas Mengatasi Masalah Kesehatan Ibu dan Anak, 2017, pp. 1-5.
[15] V. R. De Souza, A. P. Pereira, A. C. M. Pinheiro, and H. M. A. Bolini, "Original article Analysis of various sweeteners in low-sugar mixed fruit jam : equivalent sweetness , time-intensity analysis and acceptance test,” Int. J. Food Sci. Techonolgy, vol. 48, no. 1999, pp. 1541-1548, 2013.

[16] D. Sundari and Komari, "Formulation the Jam Mixture of Raja Bulu Banana With Tempe and Durability," Penelit. Gizi dan Makanan, vol. 33, no. 1, pp. 93-101, 2010.

[17] L. Ho and N. C. Dahri, "Effect of watermelon rind powder on physicochemical, textural, and sensory properties of wet yellow noodles," CYTA - J. FOOD, vol. 6337, no. February, 2016.

[18] A. Iqbal, "Drying of Watermelon Rind and Development of Cakes from Rind Powder," Int. J. Nov. Res. Life Sci., vol. 2, no. 1, pp. 14-21, 2015.

[19] M. Javanmard, N. L. Chin, S. H. Mirhosseini, and J. Endan, "Original article Characteristics of gelling agent substituted fruit jam : studies on the textural , optical , physicochemical and sensory properties," Int. J. Food Sci. Technol., vol. 47, pp. 1808-1818, 2012.

[20] M. Mushtaq and B. Sultana, "RSM based optimized enzyme-assisted extraction of antioxidant phenolics from underutilized watermelon (Citrullus lanatus Thunb.) rind," J. Food Sci. Technol., vol. 14, pp. 1011-10119, 2014 